РОЗВИТОК ПРОФЕСІЙНОЇ КОМПЕТЕНТНОСТІ МАЙБУТНІХ МАГІСТРІВ ВІЙСЬКОВОГО УПРАВЛІННЯ 3 ВИКОРИСТАННЯМ ТЕХНОЛОГІЙ ДИСТАНЦІЙНОГО НАВЧАННЯ

\title{
DEVELOPMENT OF PROFESSIONAL COMPETENCE OF FUTURE MILITARY MANAGEMENT MASTERS USING DISTANCE LEARNING TECHNOLOGIES
}

\begin{abstract}
У статті здійснено загальну характеристику особливостей застосування технологій дистанційного навчання з метою розвитку професійної компетентності майбутніх магістрів військового управління, яка є інтегративною властивістю особистості, що включає сукупність знань, навичок, вмінь у психолого-педагогічній галузі, здатність впливати на прочес розвитку і саморозвитку соціальноціннісних характеристик особистості військовослужбовців, дозволяє виконувати соціально-ціннісні фоункції у військовому колективі, попереджати й усувати вияви негативної поведінки підлеглих.

Запропоновано моделі дистанційного навчання, які доцільно використовувати в освітньому процесі вищих військових навчальних закладів. Зроблено висновок, що особливості умов проходження військової служби, високий рівень відповідальності за прийняті рішення, що сучасні технічні засоби висувають особливі вимоги до підготовки майбутніх магістрів військового управління $і$ змушують иукати засоби та методи вдосконалення освітнього процесу. Одним із варіантів вирішення цієї проблеми є використання в системі вищої професійної освіти можливостей дистанційного навчання.

Констатовано, що в основу дистанційного навчання покладена певна модель розвитку професійної компетентності 3 використанням нових інфрормаційних технологій, що сприяє підвищенню рівня інорормаційної культури. При цьому необхідно враховувати низку особливостей організації дистанційного навчання: обмежені можливості на здійснення безпосереднього контакту між викладачем $і$ здобувачами внаслідок того, що безпосереднє спілкування відбувається за допомогою засобів зв'язку і телекомунікацій; від здобувачів вимагається володіння певним рівнем освіти (певний початковий набір знань, вмінь, навичок); урахування індивідуальних потреб слухачів з апелюванням до їх віку (зазвичай здобувачі належать до різних вікових категорій).

Ключові слова: професійна компетентність, вищий військовий навчальний заклад, офріцери, інформмаційно-освітнє середовище, дистанційна освіта, змішане навчання.
\end{abstract}

The article gives a general description of peculiarities of the use of distance learning technologies in order to develop the professional competence of future military management masters. It has been summarized that the peculiarities of conditions of military service, the high level of responsibility for the deci- sions made, that the modern technical means bring special requirements for preparing future military masters management and make them search for the means and methods to improve the educational process. One of the ways to solve this problem is to use opportunities of distance learning in the system of higher professional education.

It has been stated that distance learning is based on a particular model of knowledge transfer with the use of new information technologies, which facilitates increasing the level of information culture. Herewith, it is necessary to take into account a number of peculiarities of organizing distance learning.

Firstly, it is about limited opportunities for making direct contact between a teacher and degree seeking students due to the fact that direct communication is carried out through the means of communication and telecommunications. Secondly, degree seeking students are required to have a particular level of education (a certain initial set of knowledge, abilities, and skills). Finally, it comes to taking into account the individual needs of listeners with the appeal to their age (usually, applicants belong to different age categories).

It has been established that distance learning is now regarded as one of the most important areas of development of the national educational system. Today, distance learning not only comes in line with traditional forms of education, but also inevitably creates an intense influence on their development. The experience of realizing distance learning in Ukraine and abroad has shown an expediency of using this form of education in both civic and military fields of the vocational educational system. Models of distance learning, appropriate to be used in the educational process of higher military educational institutions, are suggested. It has been summed up that significance of distance learning is confirmed both by foreign experience and by gradual implementation of technologies and methods of distance education at higher military educational institutions of Ukraine. The introduction of such a form in the process of development of professional competence of future masters of military management will enrich pedagogical science by developing methodological foundations of teachers activities using distance learning technologies. It will also raise the status of higher military educational institutions, while officers will additionally get an opportunity to develop skills of self-education and improve their knowledge in management, psychology, as well as information and telecommunication systems.

Ключові слова: professional competence, higher military educational institution, officers, informational and educational environment, $A D L$ learning, blended learning.
Національного університету оборони

України імені Івана Черняховського
Постановка проблеми в загальному вигляді. Політичні та соціально-економічні зміни, які відбуваються в нашій країні, не можуть не зачіпати сис- тему вищої військової професійної освіти. В сучасному світі науково-технічні і соціальні процеси швидко і кардинально змінюють умови праці та 
зміст професійної діяльності майбутніх магістрів військового управління. Тому безперервно змінюється і розширюється коло профессійних обов'язків і фрункцій, стає іншим характер професійних відносин. 3 метою адаптації до цих процесів людина протягом усього свого трудового життя повинна бути готовою до перенавчання, перепідготовки та постійного підвищення свого рівня професійної компетентності.

Однак ідея здобуття ступеня магістра військового управління (далі - МВУ) у професійній військовій освіті в свідомості суспільства дуже часто залишається декларативною, формально організованою і незатребуваною суб'єктами управління суспільством. Тому вдосконалення професійної підготовки та перепідготовки майбутніх МВУ вимагає пошуку ефективних шляхів, способів і засобів.

Особливості умов проходження військової служби, високий рівень відповідальності за прийняті рішення, сучасні технічні засоби висувають особливі вимоги до підготовки майбутніх МВУ і змушують шукати засоби та методи вдосконалення освітнього процесу. Одним із варіантів вирішення цієї проблеми є використання в системі вищої професійної освіти можливостей дистанційного навчання.

В основу дистанційного навчання покладена певна модель передачі знань 3 використанням нових інорормаційних технологій, що сприяє підвищенню рівня інформаційної культури. При цьому необхідно враховувати низку особливостей організації дистанційного навчання:

1) обмежені можливості на здійснення безпосереднього контакту між викладачем і здобувачами внаслідок того, що безпосереднє спілкування відбувається за допомогою засобів зв'язку і телекомунікацій;

2) від здобувачів вимагається володіння певним рівнем освіти (певний початковий набір знань, вмінь, навичок);

3) урахування індивідуальних потреб слухачів 3 апелюванням до їх віку (зазвичай здобувачі належать до різних вікових категорій).

Дистанційне навчання, почавши активно розвиватися з 90-х років XX століття, нині розглядається як один із найважливіших напрямів розвитку національної системи освіти, адже дистанційне навчання не тільки стає в один ряд із традиційними формами отримання освіти, а й неухильно впливає на їх розвиток. Досвід реалізації дистанційного навчання в Україні [1] і за кордоном [2] показав доцільність використання цієї форми навчання як в цивільній, так і у військовій сфрерах системи професійної освіти [2].

Аналіз останніх досліджень і публікацій засвідчив той фракт, що сучасні науковці у своїх розвідках звертають увагу на вивчення проблеми розвитку професійної компетентності майбутніх
МВУ. Зокрема, В. Крикун дослідила зміст і структуру іншомовної профресійної компетентності майбутніх МВУ [6]. Л. Заїка виокремила організаційно-педагогічні умови фрормування професійної компетентності в контексті застосування технології імітаційного моделювання [3] та конкретизувала особливості формування профресійної компетентності на засадах технології імітаційного моделювання [4].

В. Шемчук вивчав проблему розвитку управлінського мислення майбутніх МВУ в оперативнотактичній ланці управління [12]. Апелюючи до необхідності імплементації компетентснісного підходу у вищу військову освіту, А. Зельницький розробив компетентнісну модель випускника ВВН3, назвавши її складником системи підготовки військових фрахівців [5]. Схожої наукової позиції дотримується Л. Новікова [8].

І. Чистовська дослідила динаміку формування педагогічної компетентності майбутніх МВУ засобами технології навчання [11]. Л. Олійник дослідив загальні інтенції розвитку спеціальної компетентності магістрів військово-соціального управління [7; 9]. Однак нами не знайдено наукових публікацій, де б предметом дослідницького пошуку стала проблема застосування технологій дистанційного навчання для розвитку фрахової компетентності майбутніх МВУ. Новизна статті полягає у виявленні можливостей застосування технологій дистанційного навчання з метою розвитку профресійної компетентності майбутніх МВУ.

Метою статті визначено загальну характеристику особливостей застосування технологій дистанційного навчання для розвитку професійної компетентності майбутніх МВУ.

Виклад основного матеріалу. Традиційне програмно-методичне забезпечення процесу формування професійної компетентності майбутніх МВУ повністю вже не задовольняє потреби слухачів. Сучасний рівень розвитку комп'ютерної техніки, програмного забезпечення, нові інфрормаційні та технічні засоби доставки навчального матеріалу дають широкі можливості щодо модернізації та підвищення ефеективності процесу вищої військової освіти. Однак, незважаючи на значні потенційні можливості сучасних інфрормаційних технологій, вони ще не знайшли належного застосування в підготовці майбутніх МВУ.

Сучасний рівень розвитку інформаційно-комунікативних технологій, надаючи небаченого динамізму розвитку суспільства, створює реальні передумови для формування глобальної системи дистанційної вищої військової освіти, відкритого інорормаційного середовища 3 можливістю вільного поширення знань та інфрормації, які виходять за межі державних кордонів і національних контекстів. У зв'язку з цим розвиваються нові технології навчання, в тому числі і дистанційного, які в сукуп- 
ності 3 іншими чинниками сприяють виникненню широкому розповсюдженню нової фрорми професійної підготовки - дистанційної освіти.

Протягом останніх десятиліть дистанційне навчання стало глобальним явищем освітньої та інформаційної культури, суттєво вплинувши на характер освіти в багатьох країнах світу, де відбувається інтенсивний розвиток спектру освітніх послуг 3 використанням дистанційних освітніх технологій [2]. Їхнє застосування дає змогу швидко, адекватно і гнучко реагувати на потреби суспільства, забезпечити широкий доступ до отримання освіти, зокрема для тих, кому за низкою причин неприйнятні традиційні форми навчання, а також вирішити проблему значного розширення контингенту населення з вищою та додатковою професійною освітою.

Віртуальні 3ВО, на думку європейських аналітиків, до 2025 року стануть основним постачальником вищої освіти у світі [2]. Слід зазначити, що нині в Україні та світі накопичено значний позитивний досвід реалізації системи дистанційної освіти не як різновиду заочного навчання, а як нової самостійної фрорми професійної підготовки зі значними потенційними можливостями.

Ефективність фрункціонування системи вищої військової професійної освіти буде визначати продуктивність підготовки та перепідготовки військових фрахівців, в тому числі й майбутніх МВУ, готових мобільно вирішувати поставлені перед ними професійні завдання. Нині підготовку майбутніх МВУ не можна уявити як «статичне новоутворення» у зв'язку з особливостями військової служби, які характеризуються високим рівнем відповідальності і обмеженням часу на прийняття рішення. Внаслідок цього висуваються серйозні вимоги до військовослужбовця як до фрахівця, що спонукає його постійно підтримувати й підвищувати рівень своїх профресійних знань, навичок і вмінь, тобто рівень професійної компетентності.

Натепер під профресійною компетентністю майбутніх МВУ розуміють інтегративну властивість особистості, яка включає сукупність знань, навичок, вмінь у психолого-педагогічній галузі, здатність впливати на процес розвитку і саморозвитку соціально-ціннісних характеристик особистості військовослужбовців, дозволяє виконувати соціально-ціннісні функції у військовому колективі, попереджувати й усувати вияви негативної поведінки підлеглих. Це визначення відбиває багатоаспектність досліджуваного феномену. Забезпечення такої полізмістовності професійної підготовки майбутніх МВУ вбачаємо можливим за умови використання можливостей дистанційного навчання [10].

Вивчення досліджень, що стосуються підготовки майбутніх МВУ в умовах дистанційного навчання, дозволило виокремити низку факторів, які потребують урахування під час вибору педагогічної концепції: а) профресійного (наявність індивідуального (профресійного) досвіду, готовність до його практичної реалізації);

б) андрагогічного (особи, які вирішують здобувати ступінь магістра, здебільшого є дорослими людьми);

в) соціального (основою мотивації є усвідомлення необхідності підвищення свого професійного рівня для більш якісного виконання фрункціональних обов'язків або кар'єрного росту).

Нині дистанційне навчання - це діяльність, яка здійснюється систематично за допомогою портативних пристроїв і технологій для отримання, створення або надання навчальної інформації будьякого фрормату, забезпечення швидкого доступу до автентичних навчальних і довідкових ресурсів і програм, постійного зворотного зв'язку з викладачем і навчальним співтовариством, організації автономного навчання та створення професійно зорієнтованого навчального середовища слухача.

В сучасному науковому знанні існують чіткі класифікації моделей дистанційного навчання (далі - МДН). Розглянемо ті з них, використання яких забезпечуватиме позитивний вплив на розвиток професійної компетентності майбутніх MBУ. У науковій літературі представлено декілька класифікацій МДН за низкою критеріїв. Вперше класифрікацію моделей дистанційного навчання запропонували C. Манджуліка (S. Manjulika) та B. Редді (V. Reddy), виокремивши три основні моделі навчальних закладів, які пропонують ДН: віртуальне навчання у традиційному університеті / коледжі, віртуальне навчання в гібридному університеті, віртуальна модель університету державної власності [3]. Однак науковці упустили можливість віртуального навчання у відкритому університеті. Водночас окреслені моделі автори поділяють таким чином: модель-консорціум 3 видачею випускникам сертифрікатів (Consortium Certification Model), модель-провайдер консорціуму (Consortium Service - Provider Model), прибуткова модель (For Profit Model), корпоративна секторна модель (Corporate Sector Model), модель консорціум - глобальна багатонаціональна модель (Global Multinational Model) [2].

Орієнтація на реалізацію високого потенціалу комп'ютерних і телекомунікаційних технологій як однієї з основних тенденцій сучасної освітньої системи зумовила класифрікацію моделей ДН залежно від домінуючих у навчанні технологій, а також загального підходу до навчання:

1) консультаційна модель, яка передбачає регулярне відвідування слухачем консультаційного (навчального) центру для прослуховування лекцій, консультацій із викладачами та оцінювання виконаних самостійних робіт [1; 2; 6] (рис. 1). Перебіг навчального процесу контролюється в консультаційному центрі тьюторами. Для реалізації цієї 


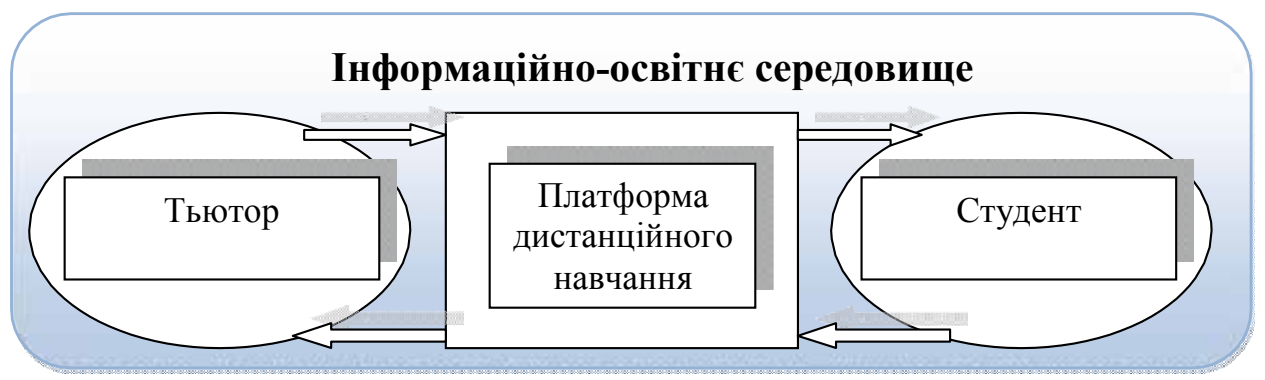

Рис. 1. Консультаційна модель дН

моделі необхідні такі умови: наявність часу для регулярного відвідування консультаційного центру; забезпеченість центру спеціальними наставниками - тьюторами; наявність сорормованої групи слухачів;

2) асинхронна модель, в основі якої - процес регулярного обміну між викладачем і слухачами навчальними матеріалами, домашніми завданнями і результатами (поштою, електронною поштою або іншими каналами зв'язку - телефон, фракс, комп'ютерні мережі) без особистого контакту.

Необхідними дидактичними умовами реалізації цієї моделі є надійна система зв'язку, хороша структура навчальних матеріалів, наявність викладачів, здатних оперативно та квалісіковано оцінити роботу студента. Водночас $€$ можливість доповнення асинхронної моделі особистими зустрічами й одиничними лекціями (рис. 2);

3) модель регульованого самонавчання спрямовується на активну самостійну роботу слухачів шляхом вільного вибору часу і місця навчання, кількості часу, який витрачається на навчання, вибір дати початку курсу і складання іспиту. Необхідною умовою реалізації цієї моделі є врахування методичної та дидактичної специфріки в розробці навчального матеріалу (Рис. 3).

Підсумовуючи, зазначимо, що окреслені технології дистанційного навчання дозволяють здійснювати освітнійпроцеснавідстані, невтрачаючиякості цього процесу, підвищуючи його рівень за рахунок індивідуалізації, активних методів навчання, двосторонньої взаємодії викладача і слухачів. Крім

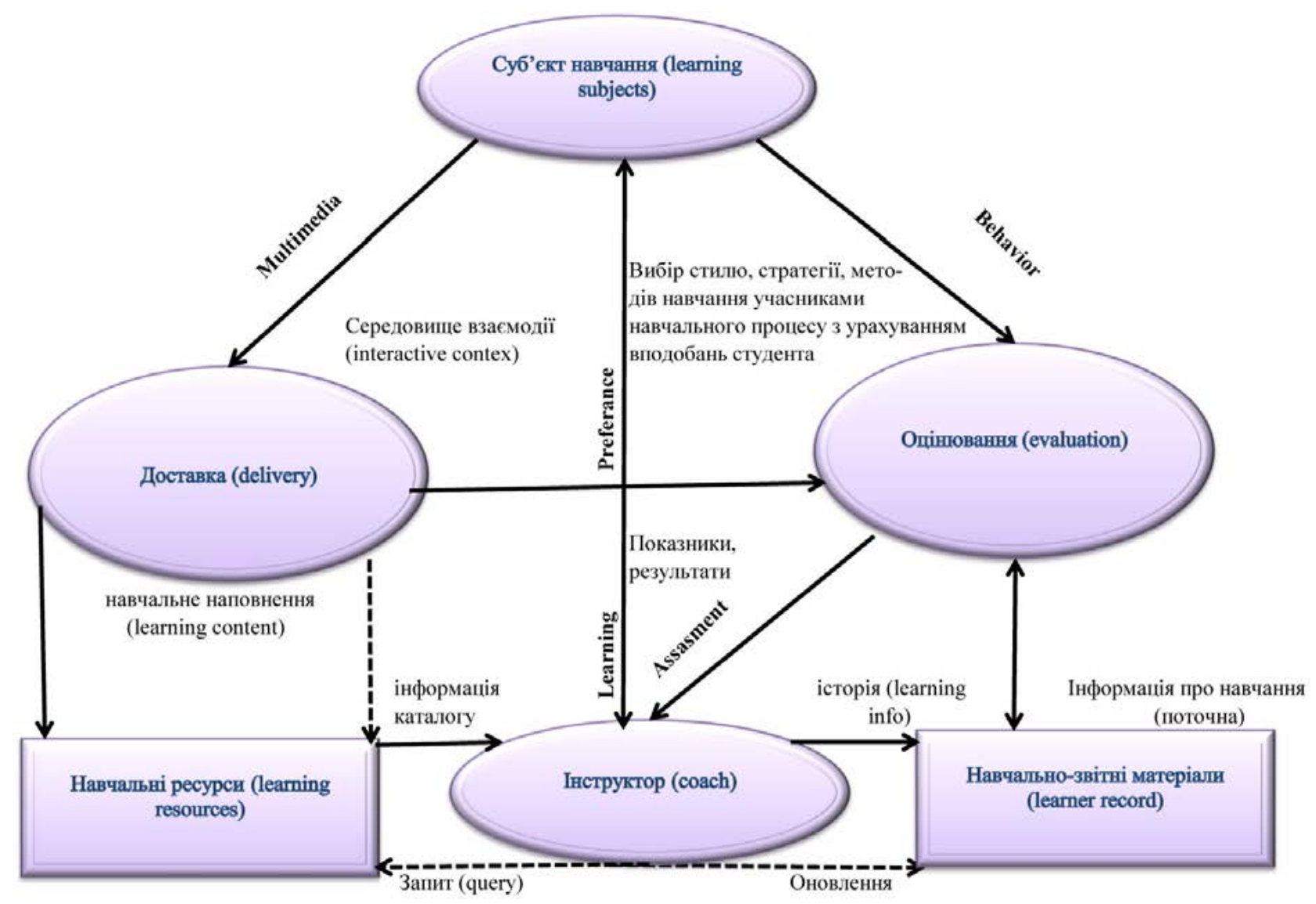

Рис. 2. Модель змішаного навчання 


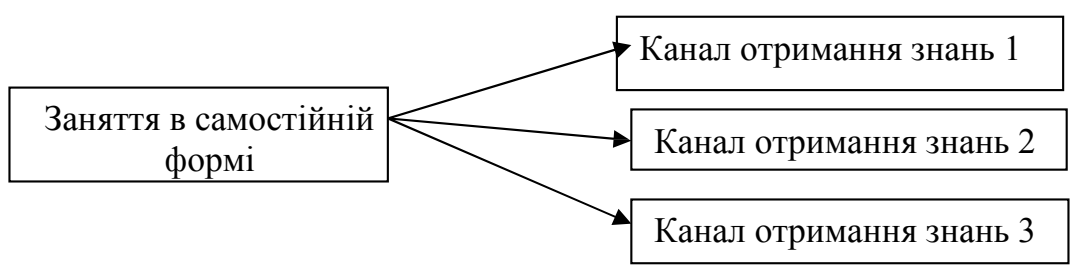

Рис. 3. Модель регульованого самонавчання

того, до переваг дистанційного навчання належать такі характерні риси, як гнучкість, модульність, технологічність, оновлення ролі педагога, підвищення мотивації та самоорганізації слухачів. Навчання при цьому стає інтерактивним, зростає значення самостійної роботи майбутніх МВУ, посилюється інтенсивність навчального процесу.

Висновки. В сучасних умовах технології дистанційного навчання $€$ актуальними, особливо в умовах впровадження нових, в тому числі інфрормаційних технологій. Важливість дистанційного навчання підтверджується як закордонним досвідом, так і поступовим впровадженням технологій і методів дистанційної освіти у ВВНЗ України.

Впровадження подібної форми в процес розвитку професійної компетентності майбутніх МВУ збагатить педагогічну науку розробкою методичних основ діяльності викладачів при використанні дистанційних технологій навчання, підніме статус BВН3, при цьому офріцери додатково отримають можливість розвивати навички самоосвіти і вдосконалювати знання 3 управління, психології, інфрормаційних та телекомунікаційних систем.

Для реалізації системи сучасної дистанційної освіти в процесі розвитку профресійної компетентності майбутніх МВУ необхідні:

-наявністьсучаснихкомп'ютернихкласів, потужних серверів, об'єднаних у єдину локальну мережу, хоча б в рамках ВВН3, які дозволять не тільки створити сайт дистанційного навчання, а й організувати електронні поштові системи, чати, відео конфреренції, пошукові системи бібліотечних даних;

- поєднання тексту, ілюстративного та медійного матеріалу, об'єднаних розгорнутим гіпертекстових апаратом і забезпечених інтерактивними сервісами (такими як тести, контрольні запитання та інше) 3 метою полегшення процесу самостійного вивчення дисципліни та підготовки слухача до ефективного спілкування з педагогом;

- вільний доступ до електронних бібліотечних фондів і мережі Інтернет з будь-якого навчального місця;

- існування сучасних інфрормаційних технологій, які поєднують цифрову техніку і систему передачі інформації (поштові системи, чати, відео конференції), наприклад інтерактивний користувацький інтерфейс, технічні пристрої, які не тільки збирають, зберігають, поширюють, створюють, комбінують і синтезують знання, а й сприяють швидкому обміну інфрормацією та документообігу в процесі навчання;

- наявність в електронній бібліотеці різноманітних електронних навчальних посібників, підручників, навчальних курсів, які як мінімум повинні відповідати сучасним вимогам;

- наявність сучасної навчально-матеріальної бази (нового озброєння і військової техніки з серійних зразків, а також тренажерів до них, сучасного лабораторного обладнання та технічних засобів навчання, периферійного обладнання, оснащеність польової навчальної бази об'єктами і комплексами бойової підготовки, полігонним обладнанням, засобами зв'язку, управління і контролю відповідно до вимог навчально-методичних комплексів).

Перспективи подальших досліджень розвитку в цьому напрямі вбачаємо у розробці методики застосування технологій дистанційної освіти для розвитку професійної компетентності майбутніх МВУ.

\section{БІБЛІОГРАФІЧНИЙ СПИСОК:}

1. Абакумова О.О. Філософрська рефрлексія френомену дистанційної освіти : автореф. дис. ... канд. фрілос. наук: 09.00.10 / Нац. пед. ун-т ім. М.П. Драгоманова. Київ, 2016. 20 с.

2. Баришполець О.Т. Медіаосвіта: закордонний досвід. URL: http:// www.politik.org.ua/vid/ magcontent. php3?m=6\&n=84\&c=2072.

3. Заїка Л.А. Організаційно-педагогічні умови формування профресійної компетентності в контексті застосування технології імітаційного моделювання. Педагогічна освіта: теорія і практика : зб. наук. пр. Кам'янець-Подільського національного університету імені Івана Огієнка, Інституту педагогіки НАПН України: у 2-х ч. 2017. Вип. 22 (1-2017), ч. 1. С. 107-113.

4. Заїка Л.А. Особливості фрормування професійної компетентності на засадах технології імітаційного моделювання. Вісник Національної академії Державної прикордонної служби України. Педагогіка. 2016. Вип. 5. URL: http://nbuv.gov. ua/UJRN/Vnadped_2016_5_9 (дата звернення: 09.04.2020).

5. Зельницький А.М. Компетентнісна модель випускника ВВНЗ - складник системи підготовки військових фрахівців / А.М. Зельницький, П.І. Удовенко, Р.М. Серветник // Вісник Національної академії оборони України : зб. наук. праць. К. : НАОУ, 2009. Вип. 3 (11). С. 26-38.

6. Крикун В.Д. Технологія змішаного навчання: теорія і практика фрормування іншомовної компетентності : навч.-метод. посіб. Київ, 2017. 172 с. 
7. Макодзей Л.І. Критерії, показники та рівні сорормованості управлінської компетентності майбутніх магістрів лісового господарства. Теорія і методика профресійної освіти, 2011. № 1. С. 12. URL: http://www.tmpe.gb7.ru/docs/1/Makodzei.pdf.

8. Новікова Л.М. Впровадження кредитномодульної системи навчання в умовах Болонського процесу. Науково-педагогічний семінар «Педагогіка вищої школи». Методичний посібник / Л.М. Новікова. Павлоград, 2010. 125 с.

9. Олійник Л. Дослідження розвитку спеціальної компетентності магістрів військово-соціального управління. Педагогічні науки, 2014. Вип. 61-62. С. 147-154. URL: http://nbuv.gov.ua/ UJRN/pena_2014_61-62_25.

10. Стасюк В.В., Толок І.В. Психолого-педагогічна компетентність як основа професіона- лізму військового фрахівця оперативно-тактичного рівня підготовки. Вісник Національного університету оборони України : зб. наук. пр. Київ, 2012. Вип. 5 (30). С. 274-278.

11. Чистовська І.П. Динаміка орормування педагогічної компетентності майбутніх магістрів військового управління засобами технології навчання. Зб наук. пр. фракультету підготовки фрахівців 3 гуманітарних питань Національної академії оборони України. Київ, 2006. № 4 (41). C. 65-68.

12. Шемчук В.А. Розвиток управлінського мислення в майбутніх магістрів військового управління в оперативно-тактичній ланці управління: критерії та показники / В.А. Шемчук // Нові технології навчання. 2010. Вип. 66, Ч. 2. C. 247-252. 